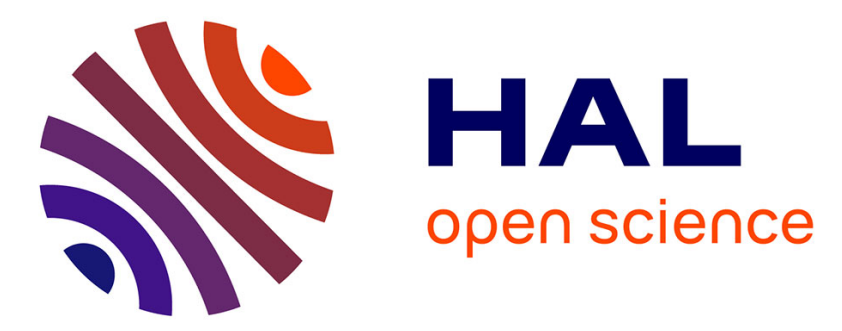

\title{
A paleoecological perspective on 1450 years of human impacts from a lake in southern Greenland.
}

Bianca B. Perren, Charly Massa, Vincent Bichet, Emilie Gauthier, Olivier Mathieu, Christophe Petit, Hervé Richard

\section{- To cite this version:}

Bianca B. Perren, Charly Massa, Vincent Bichet, Emilie Gauthier, Olivier Mathieu, et al.. A paleoecological perspective on 1450 years of human impacts from a lake in southern Greenland.. The Holocene, 2012, 22 (9), pp.1025-1034. 10.1177/0959683612437865 . hal-00725295

\section{HAL Id: hal-00725295 \\ https://hal.science/hal-00725295}

Submitted on 7 May 2020

HAL is a multi-disciplinary open access archive for the deposit and dissemination of scientific research documents, whether they are published or not. The documents may come from teaching and research institutions in France or abroad, or from public or private research centers.
L'archive ouverte pluridisciplinaire HAL, est destinée au dépôt et à la diffusion de documents scientifiques de niveau recherche, publiés ou non, émanant des établissements d'enseignement et de recherche français ou étrangers, des laboratoires publics ou privés. 


\title{
A paleoecological perspective on I 450 years of human impacts from a lake in southern Greenland
}

\author{
Bianca B Perren,' Charly Massa,' Vincent Bichet, ' Émilie Gauthier,' \\ Olivier Mathieu, ${ }^{2}$ Christophe Petit ${ }^{3}$ and Hervé Richard'
}

\begin{abstract}
A multiproxy sedimentary record from Lake Igaliku in southern Greenland documents I450 years of human impacts on the landscape. Diatoms, scaled chrysophytes, and $\mathrm{C}$ and $\mathrm{N}$ geochemistry show perturbations consistent with recent agricultural activities (post-AD 1980), superimposed upon long-term environmental variability. While the response to Norse agriculture ( AD 986-1450) is weak, the biological response to the last 30 years of modern sheep farming is marked, with drastic changes in diatom taxa, $\delta^{13} \mathrm{C}$ and $\delta^{15} \mathrm{~N}$ isotopic ratios, and a sharp increase in scaled chrysophytes. Indeed, current conditions in the lake during the last 30 years are unprecedented in the context of the last I 450 years. The dominant driver for recent changes is likely an intensification of agricultural practices combined with warming summer temperatures. Warm temperatures and agricultural disturbance together during Norse Landnám did not lead to the marked changes seen in the modern lake environment over the last 30 years. The synergistic response between increased climate warming and agriculture will likely have unanticipated effects. These findings confirm the sensitivity of Arctic lakes to external anthropogenic forcing and are the first analyses of their kind for the effects of agriculture in Greenland.
\end{abstract}

\section{Keywords}

agriculture, climate change, $\delta^{15} \mathrm{~N}$, diatoms, Greenland, Norse

Received 7 March 20II; revised manuscript accepted I5 December 20II

\section{Introduction}

Arctic ecosystems are subject to an increasing number of stressors. The effects of climate change are becoming increasingly evident in the circumpolar North in the form of accelerating glacier melt (Zwally et al., 2002), reduced Arctic Ocean summer sea ice extent (Serreze et al., 2009), and marked biological shifts in both aquatic and terrestrial ecosystems (Post et al., 2009; Smol et al., 2005). Operating at the same time is a range of anthropogenic stressors (e.g. atmospheric deposition of nutrients, persistant organic pollutants (POPs), mercury) whose ecological implications are still largely unknown (Arctic Monitoring and Assessment Programme (AMAP), 2009). Adaptation to current and future climate change requires understanding not only of the range of natural climate variability and scenarios for the future, but also the response of ecosystems and civilizations to multiple stressors.

The south coastal region of Greenland is situated within a key geographic area for understanding North Atlantic climate variability, and occupies an important place in human history. The Norse settled southern Greenland $\sim \mathrm{AD} 986$, and the population at the peak of their colony is estimated to have been between 2000 3000 (Lynnerup, 2000) and 4000-6000 (Berglund, 1986), in approximately 500 farms within the inner fjords centered near Narsarsuaq (Østerbygd) and Nuuk (Vesterbygd). Norse subsistence was based on both terrestrial animal husbandry as well as marine resources, with community-organized seal hunts accounting for larger proportions of the economy through time (Dugmore et al., 2009). Following the disappearance of the Norse, the region around the Igaliku was resettled in the 1700s and large-scale agriculture, principally sheep farming, was reintroduced in the 1920s coincident with warmer post-'Little Ice Age' (LIA) temperatures
(Vinther et al., 2010). Currently, the agricultural sector in southern Greenland is expected to grow with increased summer temperatures, extended growing seasons and more efficient farming practices (Greenland Agriculture Advisory Board, 2009).

The establishment of the Norse farms in Greenland is thought to been aided by the favourable climatic conditions of the Medieval period. The cause of the collapse of their colony however, has been the source of much speculation (McGovern, 2000). One reason is thought to be largely climate-driven: As the climate cooled with the beginning of the LIA (AD 1400-1900) and storm frequency increased (Dugmore et al., 2007a), their finely adapted lifestyle became increasingly difficult to maintain, agricultural productivity faltered, the fjords and sea routes became icechoked, seals disappeared as migration patterns changed, and access to raw materials (i.e. iron, wood) became strained, all of which hastened the collapse of the colony (Dugmore et al., 2007b, 2009; McGovern, 2000). Another hypothesis is that the demise of the Norse in Greenland was partly self-induced: The

\footnotetext{
'UMR CNRS 6249, Laboratoire Chrono-environnement, Université de Franche-Comté, France

2UMR 556I, Biogéosciences, Université de Bourgogne, France

'UMR CNRS 704I, Archéologies et Sciences de l'Antiquité, Université
} de Paris I, France

\section{Corresponding author:}

Bianca B Perren, UMR CNRS 6249, Laboratoire Chrono-environnement, Université de Franche-Comté, 16 route de Gray, 25030 Besançon cedex, France.

Email: bianca.perren@univ-fcomte.fr 


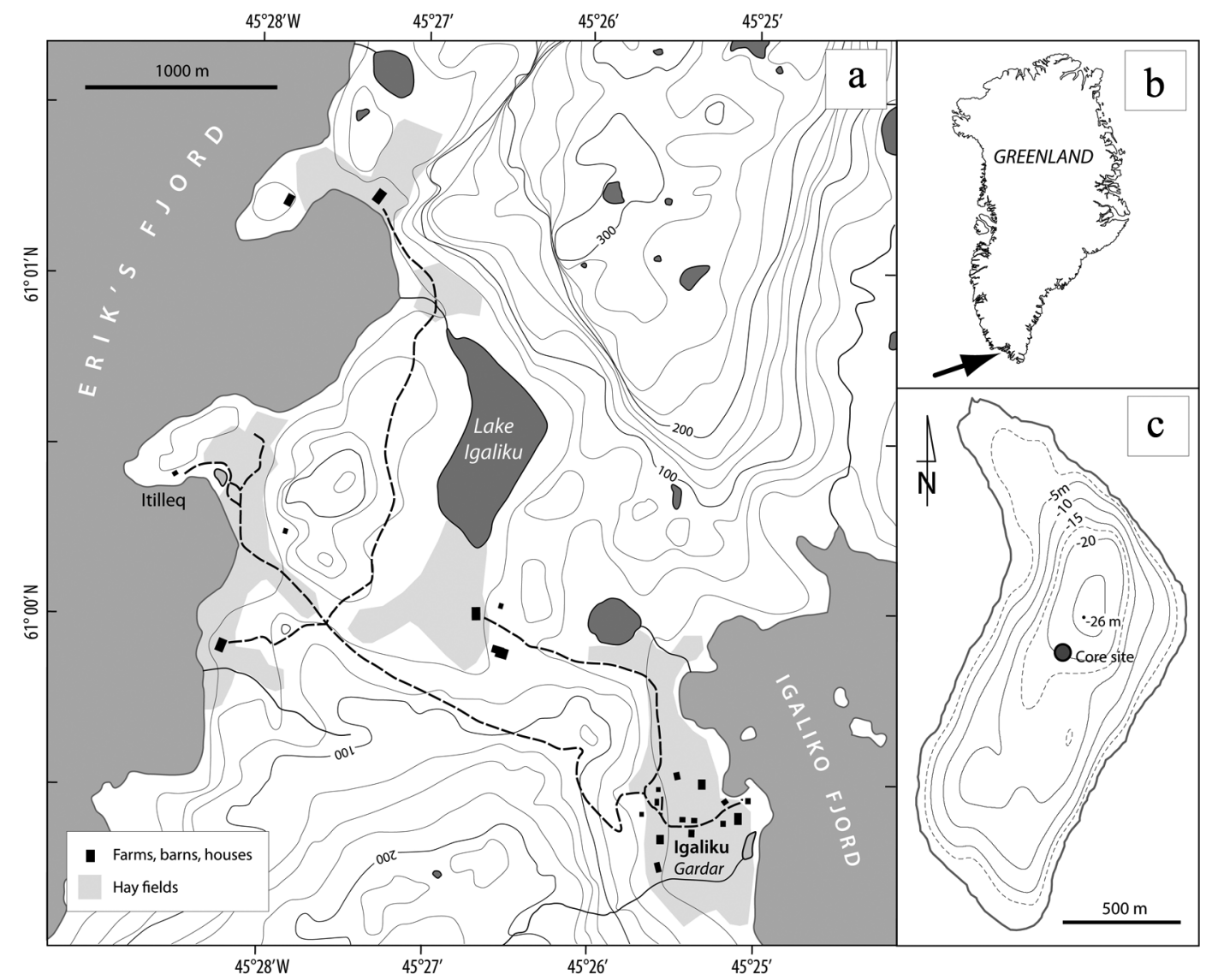

Figure I. Map showing (a) the location of Lake Igaliku on Greenland, (b) the region around Lake Igaliku including roads (dashed lines), buildings (black rectangles) and current (post-1960) hay fields (grey shaded areas) as well as the archaeological site of Gardar, and (c) the bathymetry of the lake and coring location.

grazing pressure of livestock on fragile heath tundra vegetation exceeded the resilience of the landscape and the fields became progressively denuded, erosion increased and carrying capacity fell, and the pastoral economy failed leading to the collapse of the colony (Fredskild, 1988; Jakobsen, 1991; McGovern, 2000).

The paleoenvironment of Norse sites in the North Atlantic has been studied extensively using pollen (e.g. Edwards et al., 2008; Fredskild, 1988; Gauthier et al., 2010; Schofield et al., 2008, 2010) and sedimentological analyses (Sandgren and Fredskild, 1991). While a few studies have investigated the impact of Norse activities via changes in-lake ecology using the remains of chironomids elsewhere in the North Atlantic (e.g. Faroes: Gathorne-Hardy et al., 2007; Iceland: Lawson et al., 2007), to date, no studies have used either sedimentary diatoms or carbon and nitrogen stable isotopes in lake sediments to investigate the environmental impacts of the Norse. This is despite the wide use of these paleolimnological proxies in other paleoenvironmental applications ( $\mathrm{Smol}$ and Stoermer, 2010). Diatoms, in particular, have been successfully used to trace the nature of human impacts on the landscape as early as the Neolithic and Bronze Age (Bradshaw et al., 2005; Fritz, 1989) and for disentangling the relative impacts of early human settlement patterns in boreal and temperate regions (Anderson et al., 1995; Ekdahl et al., 2004). In the Arctic, diatoms are commonly used to trace environmental responses to Holocene climate variability as well as recent warming (Smol et al., 2005; Wolfe, 2002). They have also been used to investigate other prehistoric and historic cultural impacts in the Arctic (i.e. from whaling cultures (Douglas et al., 2004) and sewage treatment (Douglas and Smol, 2000)) but have not yet been used to investigate agricultural impacts.

Despite the fact that Greenland Norse colonies are commonly thought to have been influenced by late-Holocene climate variability, to date not a single continuous, high-resolution, multiproxy paleoenvironmental record has been generated within immediate proximity of a Norse site in Greenland. Therefore, the patterns of late-Holocene natural variability are unknown at these sites, as is the extent to which Norse farming caused the purported environmental destruction often claimed. Here we present a high-resolution multiproxy biological and geochemical record from Lake Igaliku that explicitly tests the magnitude of Norse landscape impacts relative to the natural variability of the last 1450 years, and compares the period of Norse tenure (AD 986-1450) with that of modern agricultural activities (after AD 1920). This is the first analysis of this kind for Greenland and the first use of diatoms to investigate the interaction between man and the environment in this key geographic and archaeological region of southern Greenland.

\section{Methods}

\section{Study area}

Lake Igaliku $\left(61^{\circ} 00^{\prime} \mathrm{N}, 45^{\circ} 26^{\prime} \mathrm{W}, 30 \mathrm{~m}\right.$ a.s.1.) occupies a low valley between the head of Igalikup Kangerlua (Igaliku Fjord) and Tunulliarfik fjord (Erik's Fjord) in southern Greenland (Figure 1). The catchment area of the lake $\left(3.1 \mathrm{~km}^{2}\right)$ is of relatively low relief with a modern farm and pastures close to the lake and bedrock hills reaching $300 \mathrm{~m}$ a.s.l. to the south. The bedrock of the region is composed of Ketilidian Proterozoic crystalline granite overlain by the volcano-sedimentary rocks of the Eriksfjord formation, which outcrops in the hills to the northwest. This region of southern Greenland is classified as low Arctic, where permafrost is discontinuous, and birch and alder copses grow locally in the innermost sheltered fjords. Mean annual temperature is $0.9^{\circ} \mathrm{C}$, with July and January means of $10.3^{\circ} \mathrm{C}$ and $-6.8^{\circ} \mathrm{C}$, respectively. The lake is 34 ha in area and $26 \mathrm{~m}$ deep. It has one outflow, but no major inflow. 
From archaeological and written accounts, Igaliku was one of Norse Greenland's most prosperous farm regions. Originally settled by Erik the Red's daughter, Freydis, at the beginning of the Norse Landnám, it was given to the bishop in 1126 and became the site of the cathedral as well as the Thing (assembly) for the Eastern Settlement of Greenland (Jones, 1986; Sanmark, 2009). The farms are estimated to have housed between 75 and 100 cattle, in addition to sheep, and thus would have required extensive use of the surrounding land for grazing as well as hay production (Nørlund, 1936). The catchment of Lake Igaliku was never the site of a Norse farm but would have been used for grazing livestock. The modern community consists of 60 permanent inhabitants and was founded in the late 1700s. Agricultural practices resumed in the 1920s, at the same time that the climate of southern Greenland reached its recent maximum (Box et al., 2009). Current sheep farming in the catchment is limited to one farm, established in the early 1960 s, which has a barn for wintering sheep and summer hay production on a 30 ha field. A small ditch currently drains effluent from the barn into the nearby lake. The farm currently deploys 750-900 kg $\mathrm{N}$ fertilizer per year within the lake catchment to boost yields for winter fodder (Mikki Egede, personal communication, 2011).

Pollen and non-pollen palynomorph (NPP) studies from Lake Igaliku sediments reflect agricultural impacts on the landscape during Norse occupation. A decline in arboreal birch pollen $c$. AD 1000 , corresponds to an increase in exotic weed taxa (e.g. Rumex acetosa/acetosella) and a peak in coprophilous fungi, which suggest that initial birch clearance was concomitant with the use of pastures for grazing, and that sheep and cows were likely grazing in proximity of the lake during the period of Norse occupation (Gauthier et al., 2010). Following the abandonment of the settlement, the landscape did not revert to a pristine state, but retained the vegetation changes initiated by the Norse.

\section{Cores and chronology}

A suite of sediment cores was retrieved using piston and gravity cores from the deepest part of Lake Igaliku in June 2007 (see Figure 1). The $4 \mathrm{~m}$ composite sequence captures the entire Holocene (c. 10,000 years), including the marine to lacustrine transition c. $8500 \mathrm{yr} \mathrm{BP}$; however, only the upper core is discussed here (the last $\sim 1450$ years). The chronology for the core is based on 13 birch macrofossil ${ }^{14} \mathrm{C}$ dates (twigs and leaves), a ${ }^{137} \mathrm{Cs}$ peak ( $\mathrm{AD}$ 1963), and ${ }^{210} \mathrm{~Pb}$ measurements using $\alpha$ spectroscopy and the constant rate of supply (CRS) method (Appleby and Oldfield, 1978). Radiocarbon measurements were made by the Poznan Radiocarbon Laboratory and at the Université Claude Bernard 1, Lyon and were calibrated using Intcal09 (Reimer et al., 2009). Ages are reported in cal. yr BP or yr AD and an age-depth model (Figure 2) was produced using a cubic spline following Blaauw (2010). The sampling strategy reflected sedimentological characteristics (visible laminae) and 102 continuous samples (between 2 and 32 years per sample) are reported here.

\section{Diatoms and chrysophytes}

Diatoms and chrysophytes were prepared from wet sediments using a standard protocol for large sample numbers (Renberg, 1990). 5-10 $\mathrm{ml} \mathrm{30 \%} \mathrm{hydrogen} \mathrm{peroxide} \mathrm{was} \mathrm{added} \mathrm{to} \mathrm{the} \sim 0.3 \mathrm{~g}$ samples and heated until the reaction subsided, followed by the addition of several milliliters of $10 \% \mathrm{HCl}$. Samples were then rinsed with distilled water and a known quantity of Divinyl Benzene (DVB) microspheres was added to the slurries (Battarbee and Kneen, 1982), which were then dried on coverslips and mounted using Naphrax mounting medium. Using transmitted light microscopy under oil immersion at least 350 diatom valves were identified and enumerated from the slides as well as chrysophyte cysts and scales. Identification of diatoms was aided by

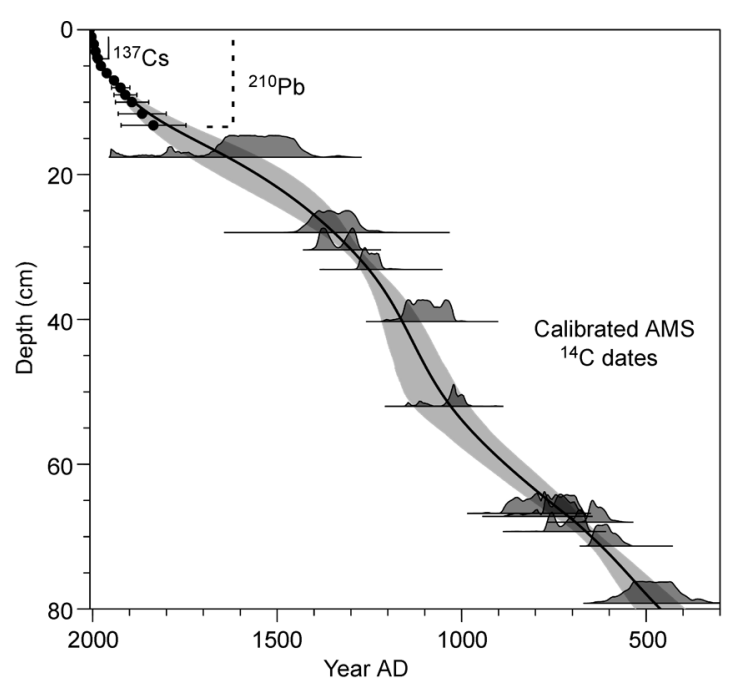

Figure 2. Age-depth model showing the dates, probabilities of radiocarbon dates and the $95 \%$ confidence interval for the age-depth model (grey band).

reference literature from Greenland (Foged, 1953, 1972, 1977) and Labrador (Fallu et al., 2000).

\section{Stable Isotopes and geochemistry}

Core samples for stable isotope and geochemistry measurements were dried and ground to fine powder prior to analysis. The total carbon and total nitrogen contents were measured by total combustion in a Vario Max CNS elemental analyser (Elementar, Germany). Mass loss of the samples was negligible after combustion at $950^{\circ} \mathrm{C}$, and thus the total carbon measured is interpreted to be organic. The $\delta^{13} \mathrm{C}$ and $\delta^{15} \mathrm{~N}$ isotopic analyses were performed in triplicate on an elemental analyser NA 1500 NCS (Carlo Erba Instruments, Milan, Italy) coupled in continuous flow mode to a stable isotope ratio mass spectrometer VG Isochrom (Micromass, Manchester, UK). The results are presented in standard delta notation. Standard errors for $\delta^{13} \mathrm{C}$ and $\delta^{15} \mathrm{~N}$ measurements are $<0.2 \%$ and $<0.5 \%$, respectively. $\delta^{13} \mathrm{C}$ measurements since $\mathrm{AD} 1840$ were corrected for the Seuss effect (Friedli et al., 1986) by subtracting the anthropogenic $\delta^{13} \mathrm{C}$ offset according to Schelske and Hodell (1995).

\section{Numerical analysis}

Principle components analysis (PCA) was performed on a covariance matrix of diatom taxa with relative frequencies $>1 \%$. PCA was chosen because the species assemblages form a short primary gradient established by detrended correspondence analysis (DCA; 1.67 SD).

A second PCA was performed on a correlation matrix of selected diatom taxa from the initial PCA (i.e. those with the highest scores: Cyclotella stelligera, Fragilaria tenera, Cyclotella rossii complex), chrysophyte scales, and geochemical data $(\mathrm{C}, \mathrm{N}$, $\left.\mathrm{C} / \mathrm{N}, \delta^{13} \mathrm{C}, \delta^{15} \mathrm{~N}\right)$. These proxies were analysed together in order to generate an overall ecological response to landscape disturbance and natural variability over the last 1450 years.

\section{Results}

\section{Diatoms and chrysophytes}

Over 140 species of diatoms from 25 genera were identified from the sediments of Lake Igaliku. Scanning electron microscope images of several of the key taxa are shown in Figure 3. The flora is typical of dimictic, circumneutral, oligotrophic West Greenlandic lakes (Perren, 2007). Cyclotella stelligera (=Discostella stelligera) 

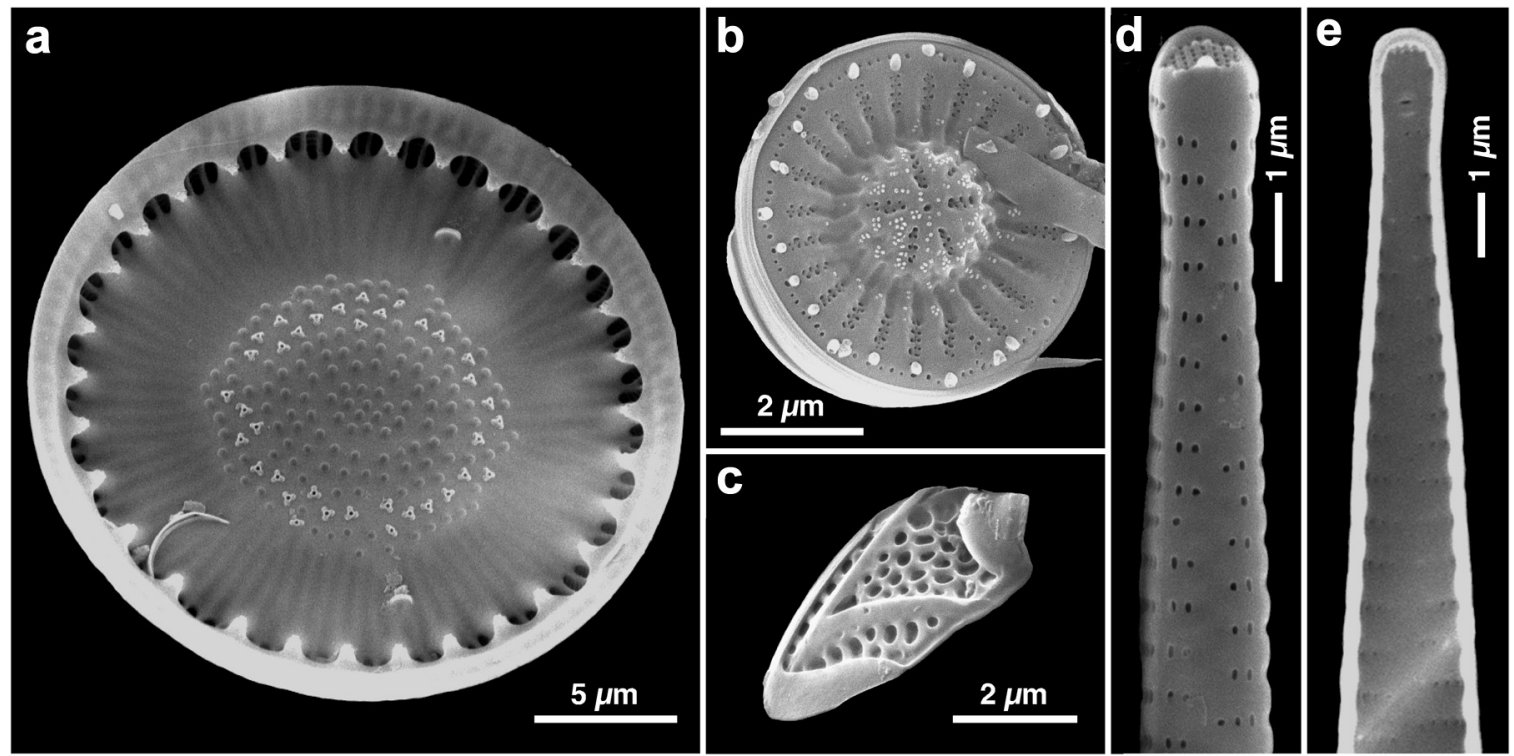

Figure 3. Scanning electron micrographs of key diatom and chrysophyte taxa from Lake lgaliku sediments. (a) Inner valve view of Cyclotella bodanica (=Puncticulata bodanica) showing central and marginal fultoportulae and two rimoportulae; (b) Cyclotella stelligera (=Discostella stelligera) showing the stellate arrangement of alveoli in the colliculate central area of the valve; (c) chrysophyte scale belonging to Mallomonas crassisquama; external (d) and internal (e) views of Fragilaria tenera showing the apical pore field and single rimportula, respectively.

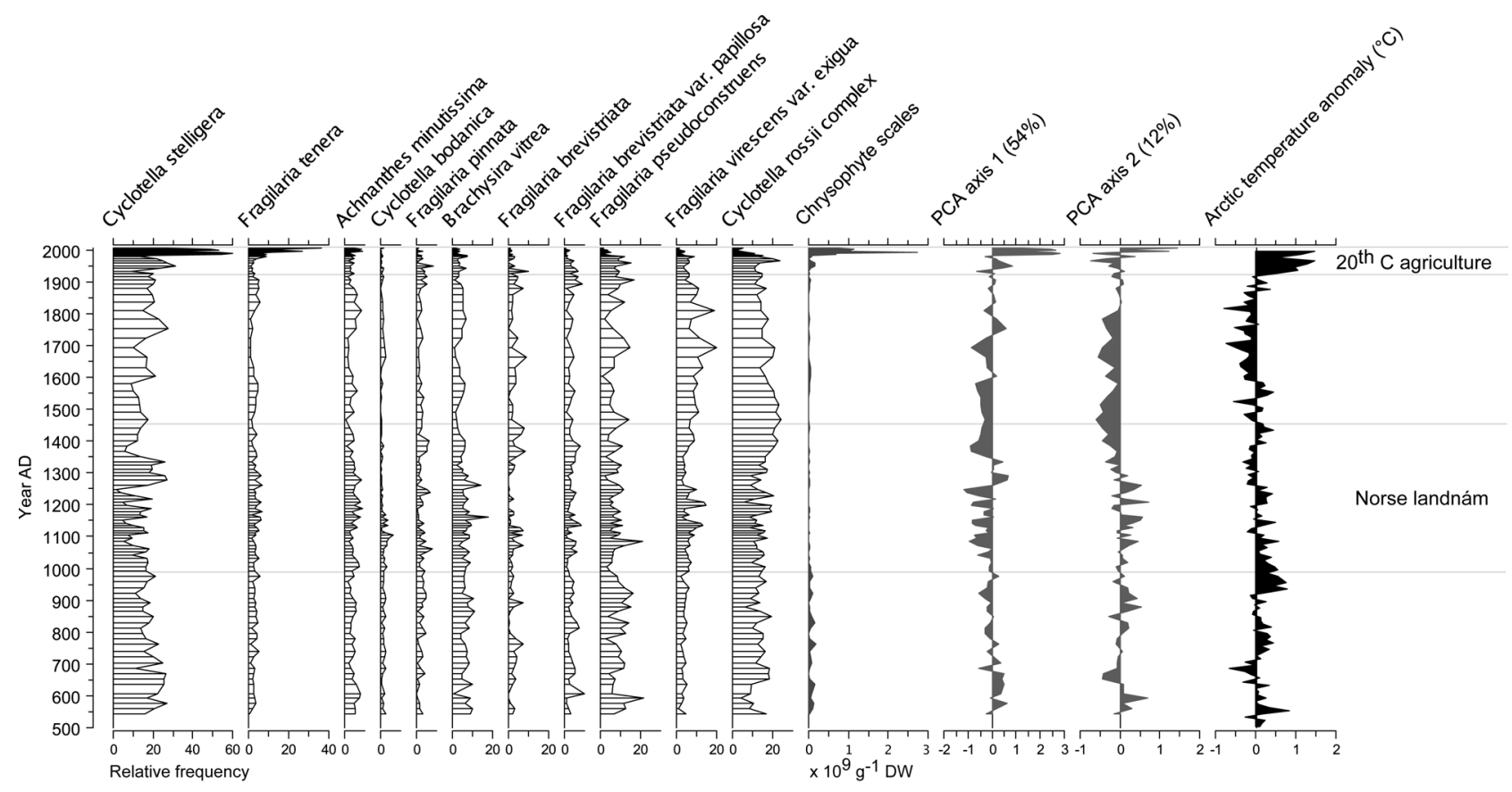

Figure 4. Stratigraphic diagram showing the relative frequency of important diatom taxa, the concentration of scaled chrysophytes, the first 2 PCA axes and the Arctic temperature anomaly reconstruction from Kaufman et al. (2009). The periods of Norse Landnám and 20th century agriculture are shown.

and the complex belonging to variants of Cyclotella rossi, $C$. comensis, C. tripartita, and C. ocellata (henceforth called Cyclotella rossii complex) dominate the planktonic component and are identical to those found along the west coast of Greenland (Perren et al., 2009) as well as those described from northeast Greenland (Cyclotella sp. A: Cremer and Wagner, 2004). Brachysira vitrea, small Achnanthes and Achnanthidium spp., and Fragilaria sensu lato (=Staurosira, Staurosirella, Pseudostaurosira, Fragilariaforma spp.) are the dominant benthic taxa. Lesser quantities of representatives of the genera Cymbella, Eunotia, Navicula, and Nitzschia are also present.

The stratigraphy of dominant diatom taxa is shown in Figure 4. The diatom assemblages are remarkably stable over the last 1450 years. The most notable exception is in the last 30 years, when Cyclotella stelligera and Fragilaria tenera increase dramatically (to maxima of $60 \%$ and $37 \%$, respectively) at the expense of the Cyclotella rossii complex. Chrysophyte scales, belonging principally to the genera Synura and Mallomonas, also increase to over $10^{9} \mathrm{scales} / \mathrm{g}$ sediment at the surface against a steady background concentration of between $0-10^{3} \mathrm{scales} / \mathrm{g}$ sediment.

Recent changes (post-AD 1980) mimic the changes seen in lakes elsewhere in the Arctic and at temperate latitudes over the last century, namely with an increase in small Cyclotella species (i.e. C. stelligera; Rühland et al., 2008) and an increase in scaled chrysophytes (Perren et al., 2009; Wolfe and Perren, 2001). Although reductions in the average cell size of Cyclotella 


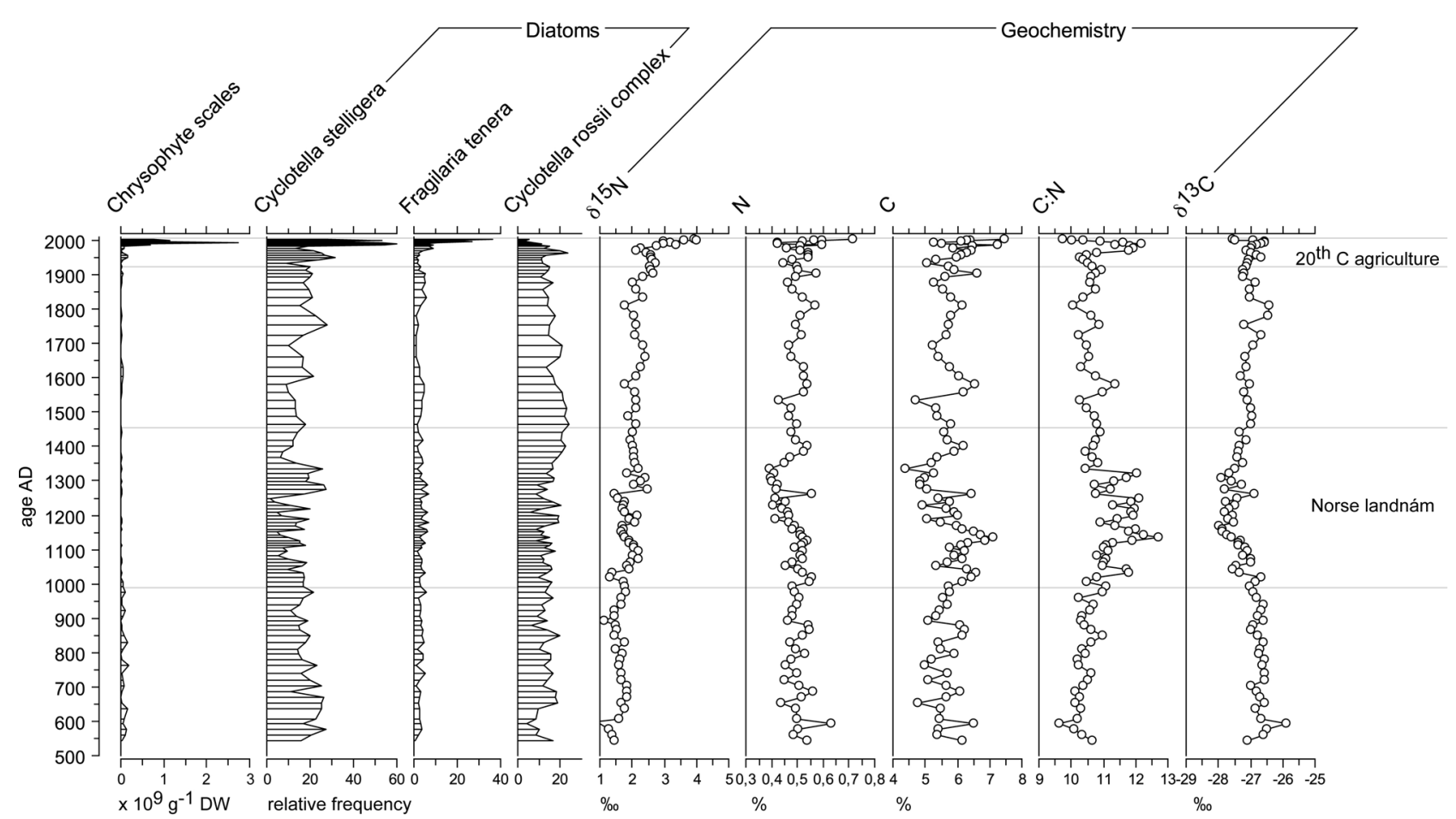

Figure 5. Stratigraphic diagram showing the proxies used in the synthesis PCA: chrysophyte scales, key diatom taxa, and geochemistry parameters. The periods of Norse settlement and modern agriculture are shown.

populations (towards smaller species such as C. stelligera) have been linked to climate warming through prolongation and strengthening of stratification patterns (Winder et al., 2009), it is yet unknown what impact slight nutrient additions may have on their distribution as well. The highest values of $C$. stelligera occur in the period following $\mathrm{AD} 1980$, with lesser peaks briefly at $\sim \mathrm{AD}$ 1750, and between $\sim \mathrm{AD} 1250$ and 1350 (Figure 4). Fragilaria tenera, a spindle-shaped planktonic taxon, occurs in only the most nutrient-enriched West Greenland lakes (Perren, 2007) and its increase here likely marks a shift towards nutrient enrichment within the last 30 years. The marked shift in scaled chrysophytes has been reported from lakes elsewhere and they have been linked to warmer conditions in Arctic lakes (Wolfe and Perren, 2001); however, their response to nutrient enrichment is unknown.

The PCA of diatom results show two major features: a major shift in lake ecology $\sim \mathrm{AD} 1980$ as registered in the PCA axis 1, and an underlying, century-scale variability captured by the second axis (Figure 4). PCA axis 1 captures profound change in beginning AD 1980, which is the major feature of the diatom record. PCA axis 1 also shows lesser positive excursions at $\sim \mathrm{AD} 1250$ 1350 , coeval with the latter part of the Norse Landnám, and in the earliest part of the record prior to $\sim \mathrm{AD} 750$. PCA axis 2 mirrors the major modes of century-scale Arctic climate variability (Kaufman et al., 2009) with positive values between $\sim \mathrm{AD} 800$ and $\sim 1300$ and negative values during the LIA $\sim$ AD 1300-1900. However, postAD 1920 warming trends in Kaufman et al. (2009) are not mirrored by the Igaliku PCA axis 2. Rather, the major inflection in the PCA axis 2 occurs in the period since AD 1980.

\section{Geochemistry}

Stable carbon and nitrogen isotopes and geochemical stratigraphies are shown alongside the principal diatom and chrysophyte stratigraphies in Figure 5. Nitrogen content values oscillate between $0.4 \%$ and $0.7 \%$ dry mass with the lowest values between $\mathrm{AD} 1200$ and 1400 and at $\mathrm{AD} 1500$. The highest values occur in the last 10 years. Similarly, total carbon reaches its highest values in the last decade with oscillations between $4.4 \%$ and $7.5 \%$ through the last 1450 years. The $\mathrm{C} / \mathrm{N}$ molar ratio is variable throughout the record ranging between 9.5 and 12.5, but highest during the period $\mathrm{AD} 1100$ and 1350 and between $\mathrm{AD}$ 1970 and 2000. The $\delta^{13} \mathrm{C}$ record is relatively stable throughout the 1450 year sedimentary profile, ranging between $-28 \%$ and $-26 \%$ with a distinct minimum between $\mathrm{AD} 1000$ and 1450, and in the last decade. The $\delta^{15} \mathrm{~N}$ slowly increases throughout the record from $0.9 \%$ at the beginning of the record to $4.0 \%$ in the uppermost sample with a slight stepwise increase beginning $\mathrm{AD}$ 1275, and the major inflection at AD 1980.

The enrichment of ${ }^{15} \mathrm{~N}$ in last 30 years in Igaliku is the inverse of observed recent trends in $\delta^{15} \mathrm{~N}$. In Greenland Ice Sheet snow and in Arctic lake sediments, $\delta^{15} \mathrm{~N}$ values decline since AD 1950 owing to the widespread atmospheric deposition of $\mathrm{N}$ from anthropogenic sources (Hastings et al., 2009; Wolfe et al., 2006). Changes to $\delta^{15} \mathrm{~N}$ can occur in lakes as a result of either internal mechanisms or changing source material. In lakes that are $\mathrm{N}$-limited, $\delta^{15} \mathrm{~N}$ will increase with increased in-lake production as the source pool of $\mathrm{N}$ gets progressively used (Hodell and Schelske, 1998). $\delta^{15} \mathrm{~N}$ also increases in lakes that receive external $\mathrm{N}$ loading from enriched sources (e.g. manure, sewage, industrial fertilizers; Teranes and Bernasconi, 2000). The rise in $\delta^{15} \mathrm{~N}$ in Igaliku is likely a result of the addition of fertilizers from manure and industrial sources, but some component of internal utilization of $\mathrm{N}$, such as enhanced sediment denitrification, cannot be ruled out.

\section{Synthesis of multiple proxies}

The PCA integrating diatoms, chrysophytes, and $\mathrm{N}$ and $\mathrm{C}$ geochemistry demonstrates the coherence of the individual proxies with each other (Figure 6a). The first and second axes explain, respectively, $36 \%$ and $20 \%$ of the variance of the data set. The first axis is strongly associated with N, Cyclotella stelligera, the concentration of scaled chrysophytes, Fragilaria tenera, and $\delta^{15} \mathrm{~N}$. The diatom complex of Cyclotella rossii dominates the negative end of the first axis. The second axis is dominated by the $\delta^{13} \mathrm{C}$ values on the positive side, and by $\mathrm{C} / \mathrm{N}$ ratio on the negative end. 
a

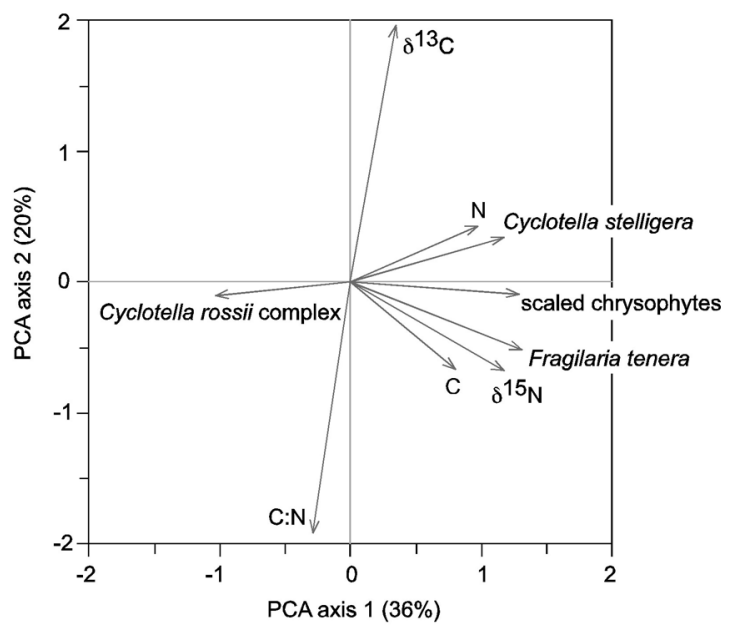

b

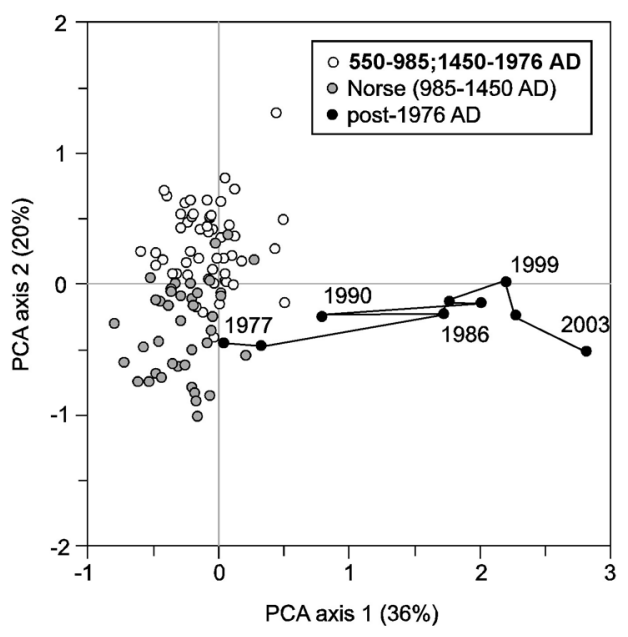

Figure 6. Synthesis PCA results. (a) PCA biplot showing the scores of the proxies used in the analysis (arrows); (b) PCA biplot of the downcore sample scores from the analysis (circles).

The PCA biplot of samples in Figure $6 \mathrm{~b}$ demonstrates the degree to which recent changes in Lake Igaliku are unprecedented. Norse samples cluster within the range of natural background values (AD 500-986; AD 1450-1976) near the origin on the negative side of both the first and second axis. Samples since AD 1976, however, display a marked shift reflecting changes in the biological and geochemical proxies, demonstrating that the ecological state of the lake beginning in the 1980s is unprecedented within the context of the 1450 year record at Igaliku.

\section{Discussion}

The biogeochemical response of Lake Igaliku documents subtle environmental changes over the last 1450 years, until c. AD 1980 when a dramatic shift occurred. In contrast with the archaeological and glaciological evidence for regional change in conditions, the biogeochemical response of the lake does not exhibit threshold-type responses to Norse farming, Medieval climate warming, or to the LIA, but rather shows low-amplitude fluctuations in an otherwise stable lake ecosystem. The relative stability of the diatom flora at Igaliku suggests that until AD 1980, the magnitude of both climatic (LIA and Medieval) and anthropogenic stressors (Norse) were not sufficient to drastically alter the biological dynamics of the lake.

\section{Scant environmental impact from Norse farming}

At Igaliku, the Norse period is registered in the sediments as slightly higher relative frequencies of the diatom taxon Cyclotella stelligera, slightly higher $\delta^{15} \mathrm{~N}$ values (both a proxy for increased production), high $\mathrm{C} / \mathrm{N}$ ratios, depleted $\delta^{13} \mathrm{C}$ values, as well as the lowest values of $\mathrm{C}$ and $\mathrm{N}$ in the last 1450 years. Sedimentological analyses (Massa et al., 2012) demonstrate a higher flux of minerogenic materials during this time, which is consistent with the $\mathrm{C}$ and $\mathrm{N}$ values shown here and with a possible soil erosion source. The peak of this signal is constrained to the period c. AD 12801350 , a time that marks the peak of the population of Norse Greenland (Lynnerup, 2000), but also the end of the Western Settlement, the beginning of the transition to colder temperatures of the LIA (Barlow et al., 1997; Jensen et al., 2004; Ogilvie et al., 2009) as well as the transition to a more marine resource-based diet (Arneborg et al., 1999). It is not possible to determine whether the subtle environmental changes are due to climate cooling, land use, or some combination of the two during this time, but it is important to note that Norse farming did not leave a significant impact on these environmental proxies.

It is an unexpected result that nearly 500 years of Norse agricultural activities are barely registered in the ecology of adjacent lake sediments. Elsewhere in the Northern Hemisphere, diatoms document nutrient enrichment in response to early agriculture by Anderson et al. (1995); Bradshaw et al. (2005); Ekdahl et al. (2004); Fritz (1989). In southern Greenland, widespread evidence from a number of nearby peat, soil, and lake sediment paleoenvironmental studies documents abrupt vegetation change (Fredskild, 1988; Schofield et al., 2008, 2010), as well as erosion and soil degradation (Jakobsen, 1991; Sandgren and Fredskild, 1991) consistent with the timing of the Norse Landnám. Entomological and $\delta^{15} \mathrm{~N}$ isotopic evidence from infields also document extensive manuring and irrigation to maximize hay production (Buckland et al., 2009; Commisso and Nelson, 2008), which would be consistent with large landscape-level disturbance and the potential for soil erosion.

The extent to which the Norse caused the systematic regional degradation of the landscape, can be questioned. Our findings echo those from the Sandøy, on the Faroe Islands, which show limited paleoenvironmental evidence of Norse landscape degradation (Gathorne-Hardy et al., 2007). Although there is little doubt from coprophilous fungal and sedimentological evidence (Gauthier et al., 2010; Massa et al., 2011) that the catchment and immediate shore of Lake Igaliku were used for grazing and therefore subject to some degree of erosion; the overall ecological impact of the Norse settlement was probably very localized.

\section{The minimal role of climate at Lake Igaliku}

Paleoclimatic archives from the circumpolar North suggest that the last 2000 years encapsulates both the warmest and coldest climates of the late Holocene (Bradley, 2000). Although warmth during the Medieval time ( $\mathrm{AD} 1000-1200$ ) is by no means hemispheric or global in nature (Bradley et al., 2003), it is well expressed in southern Greenland from a number of paleoclimatic proxies (Dahl-Jensen et al., 1998; Jensen et al., 2004; Kaplan et al., 2002). Few paleoclimatic archives exist in Greenland with which to compare the magnitude of most recent warming (post2005) with Medieval warmth, although warmest Medieval winter temperatures are purported to be on par with those of the warmest part of the middle 20th century (Vinther et al., 2010). The results presented here suggest no limnological response to warmer Medieval temperatures.

The LIA is expressed along the southwestern Greenland margin and the inland ice as a period of extreme cold, dustiness, 


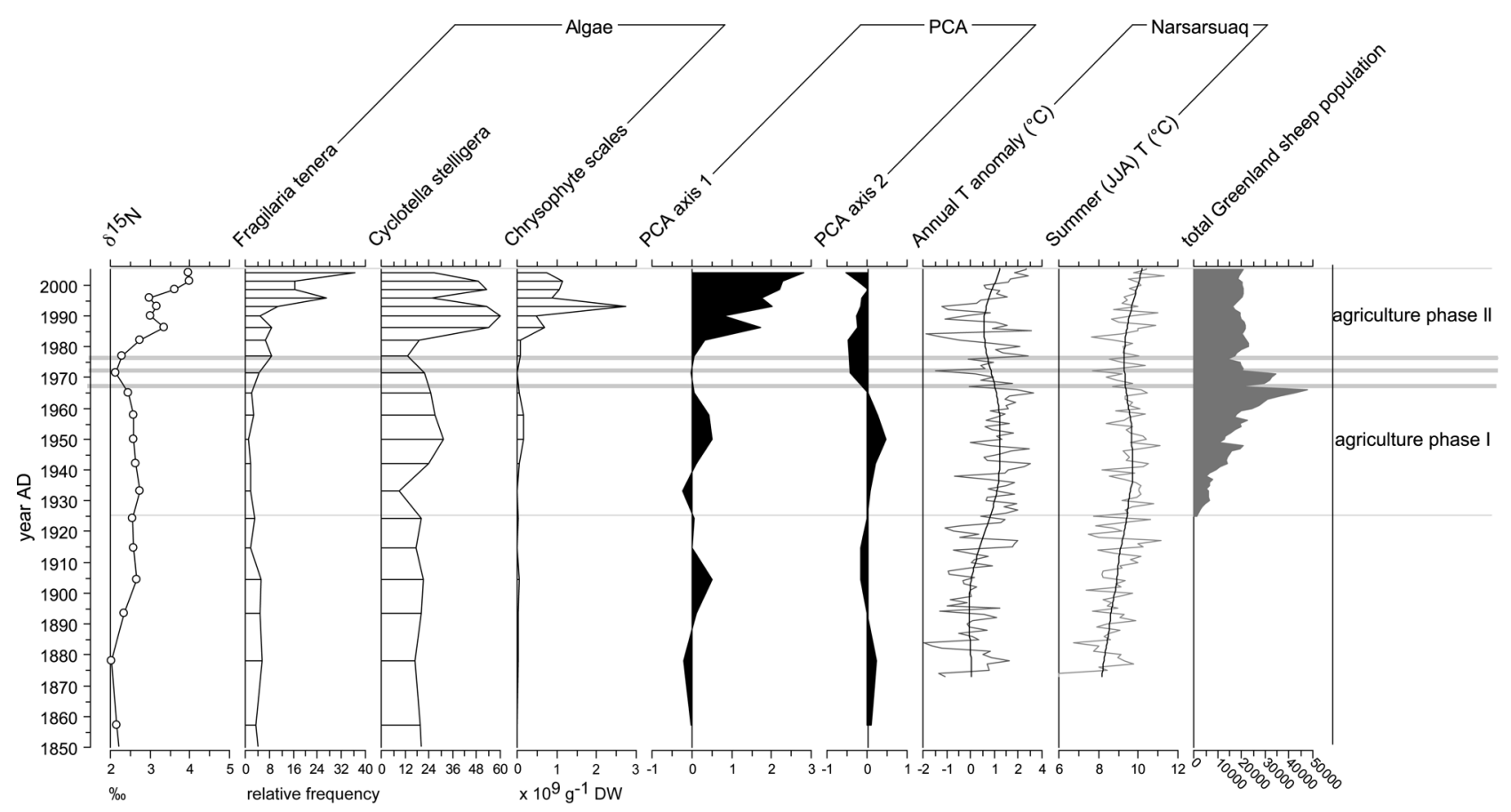

Figure 7. Stratigraphic diagram showing variations in $\delta^{15} \mathrm{~N}$, Fragilaria tenera, Cyclotella stelligera, and chrysophyte scales, the synthesis PCA axes I and 2, the mean annual temperature anomaly from the Narsarsuaq meteorological station, June, July and August (JJA) temperature from Narsarsuaq, and the total population of sheep in Greenland for the last 150 years. Grey bands mark the recent documented sheep population crises.

and drought (Andersen et al., 2006; Dahl-Jensen et al., 1998; Kaplan et al., 2002), with local glaciers achieving their lateHolocene maxima (Weidick et al., 2004). The LIA at Igaliku is marked by greater proportions of large planktonic Cyclotella species (e.g. C. rossii complex) and by Fragilaria virescens v. exigua. These shifts are consistent with a temperature-driven phytoplankton size-fraction response found by Winder et al. (2009), where warm conditions favour small phytoplankton (i.e. Cyclotella stelligera) and vice versa. The geochemical data, on the other hand, show highly variable values with no clear trend during the LIA.

\section{Medieval versus modern farming impacts:An historical analogue?}

A good historical analogue for the impact of Norse sheep farming exists: From 1920 to 1976, sheep farming in southern Greenland used methods not entirely dissimilar from the Norse. Sheep were left to forage in winter and minimal amounts of fodder were produced. The period prior to 1976 is unremarkable in the biogeochemical proxies at Lake Igaliku despite large sheep populations (upwards of 50,000 in S Greenland) on the land. However, beginning in 1976, the method of farming shifted towards fodder production and higher yields at slaughter which introduced fertilizers (250-300 kg/ha per yr) and effluent from winter sheep stables into the local landscape and lake (Figure 7: agricultural phase II; Greenland Agriculture Advisory Board, 2009). After 1976, sediments from Igaliku show a rise in planktonic diatoms (Cyclotella stelligera, Fragilaria tenera), as well as chrysophyte scales, $\delta^{15} \mathrm{~N}$, and $\mathrm{N}$, reflecting increased nutrient additions and the beginning of industrialized agriculture. These effects supercede all changes associated with the Norse Landnám.

The Norse-modern farming analogue also demonstrates the sensitivity of Arctic agriculture. In good years, between 1920 and 1976, the sheep yields in southern Greenland were high. In bad years, such as the cold, snowy spring of 1967 , nearly $60 \%$ of the sheep population perished from starvation (Greenland
Agriculture Advisory Board, 2009), with a similar situation again in 1971 and 1976 (Figure 7; Austrheim et al., 2008). The mean annual temperature for these years is $1-2^{\circ} \mathrm{C}$ below the 1873-2005 average (Figure 7; Carstensen and Jørgensen, 2010), yet had catastrophic consequences for sheep farming in Greenland. Although the Norse sheep populations were likely far smaller than those of today, two or three consecutive years with late snowy springs, as are known to have occurred throughout the last several millennia (Barlow et al., 1997; Ogilvie, 1991), could have easily crippled subsistence farming in Greenland, putting added reliance on marine resources and decreasing the resilience of the Norse in Greenland.

\section{The last 30 years at Igaliku: Multiple stressors (double trouble?)}

Determining the relative influence of climatic forcing versus land use changes on aquatic ecosystems is a difficult task, especially when the two phases of human settlement on the land coincide with the warmest periods of the last 2000 years. This is especially difficult in the Arctic, where enhanced warming will likely alter nutrient cycling dynamics. Recent climate warming since $\sim 1960$ is widely documented from a number of sites in the Arctic (Arctic Climate Impact Assessment (ACIA), 2005) and Arctic temperature trends exceed global averages two- to threefold over the last century (Trenberth et al., 2007). Despite this, warming is a relatively recent phenomenon in southern Greenland (Box et al., 2009). Meteorological records from the nearest weather station at Narsarsuaq, Greenland (1873-present; Figure 7), show that only the most recent years, since 2005 , attain the mean annual temperature maxima of the 1920-1950s, which were the warmest period of the instrumental record (Box et al., 2009; Carstensen and Jorgensen, 2010). Summer temperatures (JJA), however, show steady warming over the instrumental period with a larger increase since the 1980s (Figure 7). The fact that the well-dated upper sequence at Igaliku does not show a shift in the decades following the 1920s, but at AD 1980, concomitant with the shift in 
regional farming practices, strongly suggests that agriculture is the principal driver of ecological changes in the lake. However, the role of warming summer temperatures during this period cannot be completely ruled out.

\section{Conclusions}

The microfossil and geochemical proxy records from the last 1450 years at Lake Igaliku do not support the hypothesis that the Norse strongly impacted their environment. The five centuries of Norse farming in southern Greenland are registered in the sedimentary biological and chemical proxies as subtle deviations from long-term means, as opposed to the marked shifts documented since the advent of mechanized farming in $\sim 1976$. Similarly, the natural environmental variability of the last 1450 years is eclipsed by the recent changes seen in Lake Igaliku.

Despite subtle historical impacts, recent changes in Lake Igaliku, evidenced by marked shifts in diatoms, scaled chrysophytes, and $\delta^{15} \mathrm{~N}$, suggest that the lake is sensitive to changing land use. Recent farming activities have outpaced the geochemical and biological resilience of the lake and have likely heightened its sensitivity to future stressors. Under climate change scenarios, South Greenland is expected to warm $3-6^{\circ} \mathrm{C}$ over the next 100 years (ACIA, 2005). With additional pressure from the agricultural sector, these stressors will likely result in unanticipated new ecological states in the future. These findings confirm the sensitivity of Arctic lakes to external anthropogenic forcing and contribute to the understanding of the relative differences between the historic and modern impacts of agriculture in the North and their sensitivity to future stressors.

\section{Acknowledgements}

The authors are grateful to M Campy, H Grisey, and B Vannière for technical help in Greenland and to the farmer Mikki Egede at Igaliku and Aqqalooraq Frederiksen of the Greenland Agricultural Advisory Service in Qaqortoq, for providing information about current agricultural practices. We also thank AP Wolfe and two anonymous reviewers for providing comments on the manuscript.

\section{Funding}

Financial support for this study was provided by the University of Franche-Comté, the University of Burgundy and the French Polar Institute (IPEV).

\section{References}

Andersen KK, Ditlevsen PD, Rasmussen SO et al. (2006) Retrieving a common accumulation record from Greenland ice cores for the past 1800 years. Journal of Geophysical Research 111: D15106, doi:10.1029/2005JD006765.

Anderson NJ, Renberg I and Segerström U (1995) Diatom and lake productivity responses to agricultural development in a Northern Swedish, borealforest catchment. Journal of Ecology 83: 809-822.

Appleby PG and Oldfield F (1978) The calculation of lead-210 dates assuming a constant rate of supply of unsupported lead-210 to the sediment. Catena 5: 1-8.

Arctic Climates Impact Assessment (2005) Arctic Climate Impacts Assessment. Cambridge: Cambridge University Press.

Arctic Monitoring and Assessment Programme (2009) Arctic Pollution 2009. Oslo: Arctic Monitoring and Assessment Programme.

Arneborg J, Heinemeier J, Lynnerup N et al. (1999) Change of diet of the Greenland vikings determined from stable carbon isotope analysis and ${ }^{14} \mathrm{C}$ dating of their bones. Radiocarbon 41: 157-168.

Austrheim G, Asheim LJ, Bjarnason G et al. (2008) Sheep Grazing in the North-Atlantic Region - A Long Term Perspective on Management, Resource Economy and Ecology. Trondheim: NTNU Zoological Report 2008-3.

Barlow LK, Sadler JP, Ogilvie AEJ et al. (1997) Interdisciplinary investigations of the end of the Norse Western Settlement in Greenland. The Holocene 7(4): 489-499.
Battarbee RW and Kneen MJ (1982) The use of electronically counted microspheres in absolute diatom analysis. Limnology and Oceanography 27: 184-188.

Berglund J (1986) The decline of the Norse settlements in Greenland. Arctic Anthropology 23: 109-135.

Blaauw M (2010) Methods and code for 'classical' age-modelling of radiocarbon sequences. Quaternary Geochronology 5(5): 512-518.

Box JE, Yang L, Bromwich DH et al. (2009) Greenland Ice Sheet surface air temperature variability: 1840-2007. Journal of Climate 22: 4029-4049.

Bradley RS (2000) 1000 years of climate change. Science 288: 1353-1354

Bradley RS, Hughes MK and Diaz HF (2003) Climate in Medieval time. Science 302: 404-405.

Bradshaw EG, Rasmussen P, Nielsen H et al. (2005) Mid- to late-Holocene land-use change and lake development at Dallund So, Denmark: Trends in lake primary production as reflected by algal and macrophyte remains. The Holocene 15: 1130-1142.

Buckland PC, Edwards KJ, Panagiotakopulu E et al. (2009) Palaeoecological and historical evidence for manuring and irrigation at Garthar (Igaliku), Norse Eastern Settlement, Greenland. The Holocene 19: 105-116.

Carstensen LS and Jørgensen (2010) Weather and Climate Data from Greenland 1958-2009. Denmarks Meteorological Institute, BV DMI Technical Report 10-08, 22 pp.

Commisso RG and Nelson DE (2008) Correlation between modern plant $\delta^{15} \mathrm{~N}$ values and activity areas of Medieval Norse farms. Journal of Archaeological Science 35: 492-504.

Cremer H and Wagner B (2004) Planktonic diatom communities in High Arctic lakes (Store Koldewey, Northeast Greenland). Canadian Journal of Botany 82: 1744-1757.

Dahl-Jensen D, Mosegaard K, Gundestrup N et al. (1998) Past temperatures directly from the Greenland Ice Sheet. Science 282: 268-271.

Douglas MSV and Smol JP (2000) Eutrophication and recovery in the High Arctic: Meretta Lake revisited. Hydrobiologia 431: 193-204.

Douglas MSV, Smol JP, Savelle JM et al. (2004) Prehistoric Inuit whalers affected Arctic freshwater ecosystems. Proceedings of the National Academy of Sciences USA 101: 1613-1617.

Dugmore AJ, Borthwick DM, Church MJ et al. (2007a) The role of climate in settlement and landscape change in the North Atlantic islands: An assessment of cumulative deviations in high-resolution proxy climate records. Human Ecology 35: 169-178.

Dugmore AJ, Keller C and McGovern TH (2007b) The Norse Greenland settlement: Reflections on climate change, trade and the contrasting fates of human settlements in the Atlantic islands. Arctic Anthropology 44(1): $12-36$.

Dugmore AJ, Keller C, McGovern TH et al. (2009) Norse Greenland settlement and limits to adaptation. In: Adger WN, Lorenzoni I and O'Brien $\mathrm{K}$ (eds) Adapting to Climate Change: Thresholds, Values, Governance. Cambridge: Cambridge University Press, pp. 96-113.

Edwards KJ, Schofield JE and Mauquoy D (2008) High-resolution paleoenvironmental and chronological investigations of Norse Landnám at Tasiusaq, Eastern Settlement, Greenland. Quaternary Research 69: 1-15.

Ekdahl EJ, Teranes JL, Guilderson TP et al. (2004) A prehistorical record of cultural eutrophication from Crawford Lake, Ontario. Geology 32: 745-748.

Fallu M-A, Allaire N and Pienitz R (2000) Freshwater Diatoms from Northern Québec and Labrador (Canada). Species-Environment Relationship in Lakes of Boreal Forest, Forest-tundra and Tundra Regions. Bibliotheca Diatomologica, vol. 45. Berlin: J Cramer.

Foged N (1953) Diatoms from west Greenland. Meddelelser om Grønland 147: $1-86$.

Foged N (1972) The diatoms in four postglacial deposits in Greenland. Meddelelser om Grønland 194(4): 1-66.

Foged N (1977) The diatoms in four postglacial deposits at Godthabsfjord, West Greenland. Meddelelser om Grønland 199(4): 1-64.

Fredskild B (1988) Agriculture in a marginal area - South Greenland from the Norse landnam (985 A.D.) to the present (1985 A.D.). In: Birks HH, Birks HJB, Kaland PE et al. (eds) The Cultural Landscape - Past, Present and Future, Cambridge University Press, pp. 381-393.

Friedli $\mathrm{H}$, Lötscher $\mathrm{H}$, Oeschger $\mathrm{H}$ et al. (1986) Ice-core record of the ${ }^{13} \mathrm{C} /{ }^{12} \mathrm{C}$ ratio of atmospheric $\mathrm{CO}_{2}$ in the past two centuries. Nature 324: 237-238.

Fritz SC (1989) Lake development and limnological response to prehistoric and historic land-use in Diss, Norfolk, UK. Journal of Ecology 77: 182-202.

Gathorne-Hardy FJ, Lawson IT, Church MJ et al. (2007) The impact of the Norse Landnám on the Chironomidae (Insecta: Diptera) of lake Gróthúsvatn, Sandoy, Faroe Islands The Holocene 17: 1259-1264.

Gauthier E, Massa C, Bichet V et al. (2010) Pollen and non pollen palynomorph evidence of Medieval farming activities in Greenland. Vegetation History and Archaeobotany 19: 427-438. 
Greenland Agriculture Advisory Board (2009). Available at: http://www. nunalerineq.gl/english/landbrug/index-landbrug.htm

Hastings MG, Jarvis JC and Steig EJ (2009) Anthropogenic impacts on nitrogen isotopes of ice-core nitrate. Science 324: 1288.

Hodell DA and Schelske CL (1998) Production, sedimentation and isotopic composition of organic matter in Lake Ontario. Limnology and Oceanography 43: 200-214.

Jakobsen BH (1991) Soil resources and soil erosion in the Norse settlement area of Østerbygden in southern Greenland. Acta Borealia 8: 56-68.

Jensen KG, Kuijpers A, Koç N et al. (2004) Diatom evidence of hydrographic changes and ice conditions in Igaliku Fjord, South Greenland, during the past 1500 years. The Holocene 14(2): 152-164.

Jones G (1986) The Norse Atlantic Saga: Being the Norse Voyages of Discovery and Settlement to Iceland, Greenland, and North America. New York: Oxford University Press.

Kaplan MR, Wolfe AP and Miller GH (2002) Holocene environmental variability in southern Greenland inferred from lake sediments. Quaternary Research 58: 149-159.

Kaufman DS, Schneider DP, McKay NP et al. (2009) Recent warming reverses long-term Arctic cooling. Science 325: 1236-1239.

Lawson IT, Gathorne-Hardy FJ, Church MJ et al. (2007) Environmental impacts of the Norse settlement: Palaeoenvironmental data from M'yvatnssveit, northern Iceland. Boreas 36(1): 1-19.

Lynnerup N (2000) Life and death in Norse Greenland. In: Fitzburg WW and Ward EI (eds) Vikings. The North Atlantic Saga. Washington: Smithsonian Institution Press, pp. 285-294.

Massa C, Bichet V, Gauthier E et al. (2012) A 2500 year record of natural and anthropogenic soil erosion in South Greenland. Quaternary Science Reviews 32: 119-130.

McGovern TH (2000) The demise of Norse Greenland. In: Fitzhugh WW and Ward EI (eds) Vikings. The North Atlantic Saga. Washington: Smithsonian Institute Press, pp. 327-339.

Nørlund P (1936) Viking Settlers in Greenland and their Descendants During Five Hundred Years. Cambridge: Cambridge University Press.

Ogilvie AEJ (1991) Climatic changes in Iceland AD 865 to 1598. In: Bigelow GF (ed.) The Norse of the North Atlantic. Acta Archaeologica 61, Copenhagen: Munskgaard, pp. 233-251.

Ogilvie AEJ, Woollett JM, Smiarowski K et al. (2009) Seals and sea ice in Medieval Greenland. Journal of the North Atlantic 2: 60-80.

Perren BB (2007) Holocene lake ontogeny and recent environmental change in West Greenland. Unpublished Ph.D. thesis, University of Toronto.

Perren BB, Douglas MSV and Anderson NJ (2009) Diatoms reveal complex spatial and temporal patterns of recent limnological change in West Greenland. Journal of Paleolimnology 42: 233-247.

Post E, Forchhammer MC, Bret-Harte S et al. (2009) Ecological dynamics across the Arctic associated with recent climate change. Science 325 : $1355-1358$

Reimer PJ, Baillie MGL, Bard E et al. (2009) IntCal09 and Marine09 radiocarbon age calibration curves, 0-50,000 years cal BP. Radiocarbon 51 1111-1150.

Renberg I (1990) A procedure for preparing large sets of diatom slides from sediment cores. Journal of Paleolimnology 4: 87-90.
Rühland K, Paterson AM and Smol JP (2008) Hemispheric-scale patterns of climate-related shifts in planktonic diatoms from North American and European lakes. Global Change Biology 14(11): 2740-2754.

Sandgren P and Fredskild B (1991) Magnetic measurements recording late Holocene man-induced erosion in S. Greenland. Boreas 20: 315-331.

Sanmark A (2009) The case of the Greenlandic assembly sites. Journal of the North Atlantic 2: 178-192.

Schelske CL and Hodell DA (1995) Using carbon isotopes of bulk sedimentary organic matter to reconstruct the history of nutrient loading and eutrophication in Lake Erie. Limnology and Oceanography 40: 918-929.

Schofield JE, Edwards KJ and Christensen C (2008) Environmental impacts around the time of Norse Landnám in the Qorlortoq valley, Eastern Settlement, Greenland. Journal of Archaeological Science 35: 1643-1657.

Schofield JE, Edwards KJ, Mighall TM et al. (2010) An integrated geochemical and palynological study of human impacts and climate change from southern Greenland. Palaeogeography, Palaeoclimatology, Palaeoecology 295: 19-30.

Serreze MC, Barrett AP, Stroeve JC et al. (2009) The emergence of surfacebased Arctic amplification. The Cryosphere 3: 11-19.

Smol JP and Stoermer EF (2010) The Diatoms: Applications for the Environmental and Earth Sciences. Cambridge: Cambridge University Press.

Smol JP, Wolfe AP, Birks HJB et al. (2005) Climate-driven regime shifts in the biological communities of arctic lakes. Proceedings of the National Academy of Sciences USA 102(12): 4397-4402.

Teranes JL and Bernasconi SM (2000) The record of nitrate utilization and productivity limitation provided by $\delta^{15} \mathrm{~N}$ values in lake organic matter - A study of sediment trap and core sediments from Baldeggersee, Switzerland. Limnology Oceanography 45: 801-813.

Trenberth KE, Jones PD, Ambenje P et al. (2007) Observations: Surface and atmospheric climate change. In: Solomon S, Qin D, Manning M et al. (eds) Climate Change 2007: The Physical Science Basis. Contribution of Working Group I to the Fourth Assessment Report of the Intergovernmental Panel on Climate Change. Cambridge: Cambridge University Press, pp. 236-336.

Vinther BM, Dahl-Jensen D, Johnsen SJ et al. (2010) Climatic signals in multiple highly resolved stable isotope records from Greenland. Quaternary Science Reviews 29(3-4): 522-538.

Weidick A, Kelly M and Bennike O (2004) Late Quaternary development of the southern sector of the Greenland Ice Sheet, with particular reference to the Qassimiut lobe. Boreas 33: 284-299.

Winder M, Reuter JE and Schladow SG (2009) Lake warming favours smallsized planktonic diatom species. Proceedings of the Royal Society of London B 276: 427-435.

Wolfe AP (2002) Climate modulates the acidity of arctic lakes on millennial timescales. Geology 30: 215-218.

Wolfe AP and Perren BB (2001) Chrysophyte microfossils record marked responses to recent environmental changes in high- and mid-arctic lakes. Canadian Journal of Botany 79: 747-752.

Wolfe AP, Cooke CA and Hobbs WO (2006) Are current rates of atmospheric nitrogen deposition influencing lakes in the Eastern Canadian Arctic? Arctic Antarctic and Alpine Research 38: 465-476.

Zwally HJ, Abdalati W, Herring T et al. (2002) Surface melt-induced acceleration of Greenland Ice-Sheet flow Science 297: 218. 